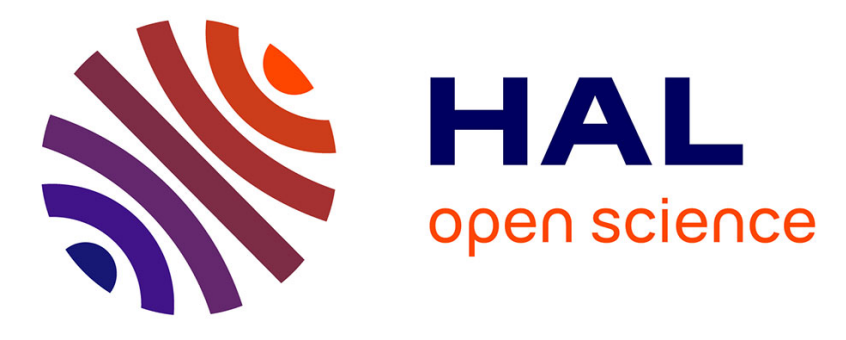

\title{
The amphipod as a bioindicator of human trampling on sandy beaches
}

\author{
Alberto Ugolini, Giuseppe Ungherese, Silvia Somigli, Giuditta Galanti, Davide \\ Baroni, Francesca Borghini, Nicola Cipriani, Massimo Nebbiai, Maurizio \\ Passaponti, Silvano Focardi
}

\section{To cite this version:}

Alberto Ugolini, Giuseppe Ungherese, Silvia Somigli, Giuditta Galanti, Davide Baroni, et al.. The amphipod as a bioindicator of human trampling on sandy beaches. Marine Environmental Research, 2008, 65 (4), pp.349. 10.1016/j.marenvres.2007.12.002 . hal-00501933

\section{HAL Id: hal-00501933 \\ https://hal.science/hal-00501933}

Submitted on 13 Jul 2010

HAL is a multi-disciplinary open access archive for the deposit and dissemination of scientific research documents, whether they are published or not. The documents may come from teaching and research institutions in France or abroad, or from public or private research centers.
L'archive ouverte pluridisciplinaire HAL, est destinée au dépôt et à la diffusion de documents scientifiques de niveau recherche, publiés ou non, émanant des établissements d'enseignement et de recherche français ou étrangers, des laboratoires publics ou privés. 


\section{Accepted Manuscript}

The amphipod Talitrus saltator as a bioindicator of human trampling on sandy beaches

Alberto Ugolini, Giuseppe Ungherese, Silvia Somigli, Giuditta Galanti, Davide Baroni, Francesca Borghini, Nicola Cipriani, Massimo Nebbiai, Maurizio Passaponti, Silvano Focardi

PII:

DOI:

Reference:

To appear in:

Received Date:

Revised Date:

Accepted Date:

$$
\text { S0141-1136(08)00004-4 }
$$$$
\text { 10.1016/j.marenvres.2007.12.002 }
$$

$$
\text { MERE } 3162
$$

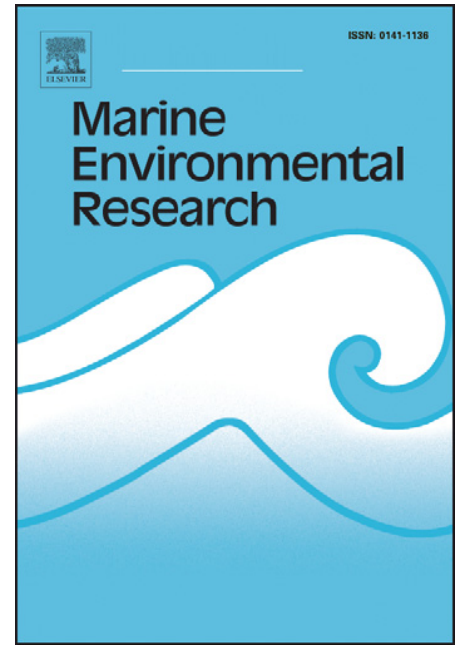

\section{Marine Environmental Research}

12 September 2007

27 December 2007

28 December 2007

Please cite this article as: Ugolini, A., Ungherese, G., Somigli, S., Galanti, G., Baroni, D., Borghini, F., Cipriani, N., Nebbiai, M., Passaponti, M., Focardi, S., The amphipod Talitrus saltator as a bioindicator of human trampling on sandy beaches, Marine Environmental Research (2008), doi: 10.1016/j.marenvres.2007.12.002

This is a PDF file of an unedited manuscript that has been accepted for publication. As a service to our customers we are providing this early version of the manuscript. The manuscript will undergo copyediting, typesetting, and review of the resulting proof before it is published in its final form. Please note that during the production process errors may be discovered which could affect the content, and all legal disclaimers that apply to the journal pertain. 


\section{The amphipod Talitrus saltator as a bioindicator of human}

2 trampling on sandy beaches

3

4 Alberto Ugolini ${ }^{\text {a, }}$ *, Giuseppe Ungherese ${ }^{\text {a }}$, Silvia Somigli ${ }^{\text {a }}$, Giuditta

5 Galanti $^{\text {a }}$, Davide Baroni ${ }^{\text {b }}$, Francesca Borghini ${ }^{\text {b }}$, Nicola Cipriani ${ }^{\text {, }}$,

6 Massimo Nebbiai $^{\text {c }}$, Maurizio Passaponti ${ }^{\text {d }}$, Silvano Focardi ${ }^{\text {b }}$ 7

$8{ }^{a}$ Dipartimento di Biologia Animale e Genetica, Università degli Studi di Firenze, Via

9 Romana 17, 50125 Firenze, Italy

$10{ }^{b}$ Dipartimento di Scienze Ambientali, Università degli Studi di Siena, Via Mattioli 4, 1153100 Siena, Italy

$12{ }^{c}$ Dipartimento di Scienze della Terra, Università degli Studi di Firenze, Via La Pira 4, 1350121 Firenze, Italy

$14{ }^{d}$ Dipartimento di Chimica Organica, Università degli Studi di Firenze, Via della

15 Lastruccia 13, 50019 Sesto Fiorentino, Italy

* Corresponding author: Tel.: +39 55 2288219, Fax: +39 55222565

18 E-mail address: ugolini_alb@dbag.unifi.it

\section{Abstract}

The present paper assesses the use of the supralittoral amphipod Talitrus saltator as a bioindicator of the effects of human trampling on the supralittoral sandy band. Samplings in delimited areas were carried out at sites subjected to different human impact. The results showed a strong negative correlation between the number of swimmers and the sandhopper population density, while there was no clear relationship between sandhopper abundance and the other factors considered: granulometry, compactness and organic carbon content of the sand, and trace metal contents in the sand and sandhoppers. A field test of trampling conducted in a confined space showed its direct negative effect on sandhopper survival. However, trace metal analysis confirmed the ability of $T$. saltator to bioaccumulate some elements $(\mathrm{Hg}, \mathrm{Zn}, \mathrm{Cu}, \mathrm{Cd})$. 
31 Our study demonstrates that $T$. saltator is a good bioindicator of human impact in the 32 supralittoral zone of sandy shores.

34 Keywords: Human trampling, Heavy metals, Mediterranean Sandy shores, Beaches,

35 Bioindicator, Amphipod, Talitrus saltator.

\section{Introduction}

In the coastal zone, the input of materials and substances from terrestrial, fluvial and marine sources is particularly important. In addition to elevated concentrations of nutrients, there can be increased quantities of natural and anthropogenic contaminants. Since the 1960s, European shores (particularly Italian ones) have seen a very strong increase in the number of swimmers at beach resorts. Many studies on the submerged and intertidal littoral environment of rocky and sandy shores have dealt with the use of organisms as biomonitors of trace metal contamination. Similarly, many investigations have attempted to evaluate the effects of human trampling and recreational uses on natural populations and communities of the littoral zone of sandy shores (see Milazzo et al., 2002 for a review). In contrast, the supralittoral band, an ecotonal environment of great ecological importance in the economy of sandy shore ecosystems, has received relatively little attention (see Brown and McLachlan, 1994; Schlacher et al. 2007).

Most research on the effects of trampling on natural communities concerns the vegetation or macrofaunal components (especially birds) (Liddle, 1975; Brown and McLachlan, 1994). Several studies have examined the effects of trampling on the invertebrate fauna of rocky shores or of loose substrata of the intertidal zone (for instance see Povey and Keough, 1991; Brosnan and Crumrine, 1994; Chandrasekara and Frid, 1996; Casu et al., 2006; Dye, 2006; Johnson et al., 2007). Instead, there have been very few investigations of the supralittoral fauna of sandy shores and the results of these studies have been contradictory (Jaramillo et al., 1996; Moffet et al., 1998; Weslawski et al., 2000b, c; Veloso et al., 2006). Recent studies have attempted to

60 establish the utility of supralittoral amphipods as indicators of the impact of tourist 61 activities on sandy shores (Fanini et al., 2005). However, because of their methods and 62 sampling sites, the investigations have not provided clear results. 
63

64

65

66

67

68

69

In summer, the supralittoral zone is intensely frequented by swimmers but it is also where the major consumers of stranded organic material, i.e. talitrid amphipods and isopod, find shelter during the day, buried in the wet sand. In fact, most of the energy flow deriving from the use of stranded material passes through supralittoral crustaceans (Branch and Branch, 1981; Griffiths et al., 1983; Brown and McLachlan, 1994). Sandhoppers occupy a trophic niche as detritivores and collector-gatherers. Hence they feed on plant and animal material from both marine and terrestrial sources (Palluault, 1954; Wildish, 1988; Bergerard, 1989), integrating the two routes of contamination of the supralittoral.

The aims of the present study were to examine the possibility of using the amphipod T. saltator as a bioindicator of the effects of human trampling on the supralittoral of sandy shores and to provide a simple low-cost monitoring tool. For this reason the relationship between sandhoppers abundance and swimmers has been considered, as well as the possible influence of some other factors such as granulometric composition and sand compactness, organic carbon content in the sand and trace metal contamination.

\section{Materials and methods}

\subsection{Sandhopper sampling}

Samplings to determine the density of sandhoppers were carried out at eight sites on the coast of Tuscany subjected to different tourist impact and either with or without beach cleaning procedures. In the five sites inside the Regional Park of Migliarino, San Rossore, Massaciuccoli (MSRM Park, Pisa), the sampling was performed once a month from June to September 2004, 2005 and 2006:

O1) Oasi 1 (cleaned beach) SM) Serchio Mare (seashore, not cleaned) $\mathrm{SF}$ ) Serchio Fiume (right bank of river mouth, not cleaned) BV) Batteria Vecchia (not cleaned) FM) Fiume Morto Vecchio (not cleaned) 
94

116 The trace metal analysis was conducted on sand samples collected from the zone

117 frequented by the sandhoppers during the day and on adult individuals of $T$. saltator

118 collected at all the sites. The animals were transported to the laboratory in plastic

119 containers with sand and detritus from the sampling site and then sacrificed by freezing.

120 At each site, a sample of sand was collected in the zone frequented by the sandhoppers

121 during the day. We dehydrated the samples at $40^{\circ} \mathrm{C}$ until they reached a constant weight

At the three sites along the Feniglia sandbar (southern Tuscany, Grosseto), the FA) bathhouse (Ansedonia side, cleaned beach) FB1) beach ca. $1 \mathrm{~km}$ from FA (cleaned)

FB2) beach ca. $2 \mathrm{~km}$ from FA (cleaned)

At each sampling, all the sandhoppers were captured (also disturbing the surface layer to sample those in the sediment) and counted inside four areas $\left(75 \mathrm{~cm}^{2}\right.$ each) delimited by plastic containers inserted a few $\mathrm{cm}$ into the sand. Each container was inserted along the sea-land axis of the beach at a progressively increasing distance starting from the water line until the beginning of dry sand. At each site, the sampling was carried out twice, a few meters apart, since the distribution of sandhoppers in the band of wet sand does not seem to be uniform (Weslawski et al., 2000a).

At each sampling site, the people to the right and left of the shoreline, along a $150 \mathrm{~m}$ transect in the central hours of the day on the days with the highest tourist presence, were also counted (Saturday and Sunday).

At some locations, the following factors were also analyzed to exclude differences between the sampling sites: 1) contents of trace metals in the sand and in the sandhoppers ( $\mathrm{Hg}, \mathrm{Cr}, \mathrm{Cd}, \mathrm{Cu}, \mathrm{Zn}, \mathrm{Fe}, \mathrm{Al}, \mathrm{Pb}) ; 2$ ) compactness of the sand; 3) granulometric composition of the sand; 4) organic carbon content of the sand.

\section{$2.2 \quad$ Trace metals} and then were finely ground. Around $150 \mathrm{mg}$ of each sample were mineralized in Teflon vessels containing $3 \mathrm{ml}$ of $\mathrm{HNO}_{3}$ at $120^{\circ} \mathrm{C}$ for $8 \mathrm{~h}$. After digestion, the solution was brought to a volume of $10 \mathrm{ml}$ by addition of deionized water. During each 
125 mineralization, we performed several "blank trials", by putting only the reagents in the

126 Teflon containers, to verify the absence of contamination.

127 The analyses were performed by atomic absorption spectrometry. $\mathrm{Cd}, \mathrm{Cr}, \mathrm{Cu}$

128 and $\mathrm{Pb}$ were determined by atomization with a graphite furnace and Zeeman

129 background corrector. The FIMS (Flow Injection Mercury System) was used for $\mathrm{Hg}$,

130 while we determined Al, Fe and Zn by Inductively Coupled Plasma Atomic Emission

131 Spectrometry (ICP/EAS). Each analysis was carried out 3 times and the accuracy of the

132 analytical procedures was assessed by comparing the results of contemporary digestions

133 and analyses of Standard Reference Materials, SRMs): SRM 1566a "oyster tissue" from

134 the National Institute of Standards and Technology (NIST, Gaithersburg, USA). The

135 results of the determination were only accepted if the values measured for the SRMs

136 were within the certified concentration range; if not, we repeated the analyses. The

137 element concentrations (expressed as $\mu \mathrm{g} / \mathrm{g}$ ) were calculated by the method of "internal

138 additions". The coefficients of variation for the various elements were between 5 and

$13910 \%$.

\subsection{Granulometric composition and sand compactness}

For the granulometric analysis, the sand samples were split to obtain samples of approximately 10 grams (the choice of the representative volume was based on the median of the sediment, as estimated by visual examination).

146 A statistically representative portion of the sample was placed in an oven at $80^{\circ} \mathrm{C}$ to

147 eliminate the humidity, after which we sifted the material through a series of

148 progressively finer sieves $(2500 \mu \mathrm{m}, 1600 \mu \mathrm{m}, 1000 \mu \mathrm{m}, 630 \mu \mathrm{m}, 400 \mu \mathrm{m}, 250 \mu \mathrm{m}, 160$

$149 \mu \mathrm{m}, 100 \mu \mathrm{m}, 63 \mu \mathrm{m})$ for around 5 minutes with a Ro-Tap shaker. Since the samples

150 were prevalently sandy, it was not necessary to analyze the mud-clay fraction $(<63 \mu \mathrm{m})$

151 of the sediment.

152 To assess the compactness of the sand in the zone frequented by sandhoppers

153 during the day, an aluminum pole was dropped from a height of $1 \mathrm{~m}$ and the distance

154 the pole penetrated into the sand was measured. The distance was transformed into

155 arbitrary units by assigning a value of $100 \%$ compactness to $0 \mathrm{~cm}$ and $50 \%$

156 compactness to $10 \mathrm{~cm}$. 


\subsection{Organic carbon}

The sand samples were collected at each site in July 2006. The organic carbon in the sand samples was determined as the difference between the total carbon and the inorganic carbon. The sand was crushed to a fine powder so as to homogenize the sample. Total carbon was determined with a CHNS/O ANALYZER (mod. 2400 ser. II, Perkin Elmer), while inorganic carbon was measured with a De Astis calcimeter.

\subsection{Trampling test}

The trampling test was carried out at Fiume Morto Vecchio (MSRM Park). Two plastic cylinders $(110 \mathrm{~cm}$ diameter) were fixed in the sand in the wet band frequented by sandhoppers during the day. All the individuals inside each of the delimited areas were captured, counted and then freed within the same area. After around 15 minutes (sufficient time for the sandhoppers to return to their refuges in the wet sand), two people performed 400 footsteps in 15 minutes inside one of the two cylinders. The number of footsteps was chosen on the basis of the footsteps recorded during a survey carried out from 11:00 to 12:00 on a Saturday in July 2006 on the Marina di Pietrasanta beach (a popular beach on the Tuscan coast). During this survey, a mean transit of 866 swimmers per hour at a selected point on the shoreline was recorded. The sandhoppers within the other cylinder were left undisturbed. At the end of the trial, the sandhoppers still alive in both cylinders were captured, counted and transported to the laboratory in basins with wet sand. The numbers of individuals still alive 24 hours after the treatment was also recorded.

\subsection{Statistical analysis}

The granulometric data were analyzed with specific software (Dept. of Earth Sciences, Univ. of Florence) that provided parametric statistics indicative of the sorting

187 of the samples, as well as the percentages of the granulometric classes for the purposes

188 of textural classification (Shepard, 1954). 
The statistical analysis of sandhopper density was performed independently of an analysis of natural population fluctuations (see Anastácio et al., 2003; Marques et al., 2003) and/or a comparison of the population densities at different sites. Such analyses were beyond the scope of our study and would not have provided information useful for our aims. It is possible that sandhopper populations living in the same environment and practically at the same latitude (ca. $200 \mathrm{~km}$ apart) present small differences in the natural fluctuation of population density. However, since we performed relative comparisons of the number of captured individuals among several localities of the same zone, any differences in population density between different zones in the same period of the year would not affect the interpretation of the results. The tests used are among the most common ones in non-parametric statistics (Zar, 1984; Siegel and Castellan, 1989).

The possible influence of trace metal pollution on sandhopper density was assessed with the Spearman rank-order correlation coefficient test (Siegel and Castellan, 1989). In the figure illustrating trace metal pollution, we arranged the sampling sites in decreasing order of sandhopper density: the site with the highest sandhopper abundance in July $2006($ FM, captured sandhoppers $=1013)$ was given the arbitrary value of 100 .

\section{Results}

\subsection{Sandhopper density}

214 sizes, statistical significance was reached for each of the four months (June-September)

215 (June and July, $\mathrm{r}_{\mathrm{s}}=-1, \mathrm{p}=0.01$; August and September, $\mathrm{r}_{\mathrm{s}}=-0.925, \mathrm{n}=5, \mathrm{p}<0.05, \mathrm{n}=$

216 5, Spearman rank-order correlation coefficient test, Fig. 1). This is also confirmed

217 considering the mean number of sandhoppers and swimmers (Table 1). In fact, the

218 Fiume Morto Vecchio site (FM) consistently had the lowest tourist impact and the

219 highest sandhopper abundance (Table 1). In contrast, no sandhoppers were found at the

220 site with the highest tourist impact, Oasi 1 (Table 1). 


\section{ACCEPTED MANUSCRIPT}

221

222

223

224

225

226

227

228

229

230

231

232

233

234

235

236

237

238

239

240

241

242

243

244

245

246

247

248

249

250

251

252

\section{FIG. 1}

\section{TABLE 1}

The July vs. September comparison for the various sampling sites was statistically significant for the localities in the MSRM Park $(G=114.5$, df $=4, p<0.001$, fig. 1) but not for the sites on the Feniglia sandbar $(\mathrm{G}=1.9$, $\mathrm{df}=2, \mathrm{p}>0.1, \mathrm{G}$ test, Fig 3).

There was a significant monthly difference in sandhopper abundance even at a single locality with very low tourist impact (Fiume Morto Vecchio, Table 1, Fig. 2, G = $664, \mathrm{df}=1, \mathrm{p}<0.001, \mathrm{G}$ test $)$ due to the natural population fluctuation. However, these differences did not affect the swimmers-sandhoppers relationship.

FIG. 2

It was not possible to make statistical comparisons for the Feniglia sandbar (Fig. 3) because of the small number of sampling sites. Nevertheless, the number of sandhoppers captured at the Feniglia sites clearly followed the same trend in relation to tourist impact as the one recorded at the MSRM Park sites, i.e. localities with higher tourist impact had lower $T$. saltator densities.

\section{FIG. 3}

Regarding the possible influence of beach cleaning on sandhopper survival, there was a significant difference between the only cleaned site $(\mathrm{O} 1, \mathrm{n}=0)$ and the total of the other MSRM sites $(\mathrm{SM}+\mathrm{SF}+\mathrm{BV}+\mathrm{FM}, \mathrm{n}=7551 ; \mathrm{G}=10434$, df $=1$, $\mathrm{P}<0.0001, \mathrm{G}$ test). However, there were also significant differences among the not cleaned sites $(\mathrm{SM}, \mathrm{n}=28 ; \mathrm{SF}, \mathrm{n}=164 ; \mathrm{BV}, \mathrm{n}=2160 ; \mathrm{FM} \mathrm{n}=5$ 199; $\mathrm{G}=10077$, df = 3, $\mathrm{P}<0.0001, \mathrm{G}$ test). A similar result was obtained for the cleaned beaches of the Feniglia sandbar (FA, $n=131 ; F B 1, n=41 ; F B 2, n=3 ; G=164$, df $=2, P<0.01, G$ test).

\subsection{Trace metals}

At the sites with sandhoppers, the $\mathrm{Cu}, \mathrm{Cd}, \mathrm{Hg}$ and $\mathrm{Zn}$ concentrations (Fig. 4) were constantly higher in the sandhoppers than in the sand. In contrast, the $\mathrm{Fe}, \mathrm{Pb}$ and $\mathrm{Al}$ contents (Fig. 4) were higher in the sand than in the sandhoppers. For $\mathrm{Cr}$, there was a 
253

254

255

256

257

258

259

260

261

262

263

264

265

266

267

268

269

270

271

272

273

274

275

276

277

278

279

280

281

282

283

284

higher concentration in the sandhoppers at two sites and in the sand at the other two sites.

There was no significant correlation between sandhopper abundance (in Fig. 4 abscissa, the sites are in decreasing order of abundance) and trace metal contents in the individuals or in the sand $(\mathrm{P}=\mathrm{NS}$ in each case, $\mathrm{n}=6$, Spearman rank-order correlation test).

\section{FIG. 4}

\subsection{Granulometric composition and sand compactness}

The granulometric composition of the sand was fairly uniform among sites: all samples were well classified and in the medium- to coarse-grained range (Table 2).

\section{TABLE 2}

For the MSRM Park sites, there was no correlation between mean sand grain diameter and sandhopper density (Spearman rank-order correlation coefficient test, $\mathrm{r}_{\mathrm{s}}=$ $-0.1, n=5, p=N S$, Fig. 5A). A qualitative evaluation also suggested a lack of correlation between sandhopper abundance and mean sand grain diameter at the Feniglia localities (Fig. 5B).

Sand compactness at the MSRM Park sites (Fig. 5C) was not significantly correlated with the number of sandhoppers $\left(\mathrm{r}_{\mathrm{s}}=-0.175 ; \mathrm{n}=5, \mathrm{p}=\mathrm{NS}\right.$, Spearman rankorder correlation coefficient test). Indeed the highest values occurred at site SF where sandhoppers were present (Fig. 5C). For the Feniglia sites, a qualitative evaluation indicated a negative correlation between sand compactness and sandhopper abundance (Fig. 5D).

\subsection{Organic carbon}

For the MSRM Park sites, the organic carbon content of the sand was not significantly correlated with sandhopper density $\left(\mathrm{r}_{\mathrm{s}}=0.7, \mathrm{n}=5, \mathrm{p}=\mathrm{NS}\right.$; Spearman rank-order correlation coefficient test, Fig. 5E). However, the localities along the Feniglia sandbar showed a negative correlation between the two parameters (fig. 5F). 


\section{ACCEPTED MANUSCRIPT}

285

286

287

288

289

290

291

292

293

294

295

296

297

298

299

300

301

302

303

304

305

306

307

308

309

310

311

312

313

314

315

\section{FIG. 5}

\subsection{Trampling test}

The effect of trampling on T. saltator survival (Fig. 6) was evident immediately after the treatment: the difference between the number of live individuals before and after treatment was highly significant $(\mathrm{G}=86, \mathrm{df}=1, \mathrm{p}<0.001, \mathrm{G}$ test $)$. After 24 hours, the percentage of surviving sandhoppers dropped almost to zero $(\mathrm{G}=428 \mathrm{df}=1$, $\mathrm{p}<0.001, \mathrm{G}$ test) while the survival of the control sandhoppers remained the same.

\section{FIG. 6}

\section{Discussion}

Of all the factors that might have negatively influenced the population density of T. saltator, only the number of swimmers showed a significant correlation with the number of captured sandhoppers. Although the effect of trampling in a confined test space is probably not the same as in natural conditions (in which case the animals could escape), our test results are the first direct proof that human trampling affects sandhopper survival. This is likely an important factor at Mediterranean latitudes and for species that burrow only slightly into the sand (ca. 3- $5 \mathrm{~cm}$ depth).

This does not mean that other factors are never influential, only that they are not particularly important in the conditions encountered in this study. Sand compactness probably has a negative effect on sandhopper abundance beyond a certain threshold: a particularly compact substrate could hinder burrowing, thus reducing the probability of survival. However, sites like BV and SF, where sandhoppers were present, had more compact sand than O1, where sandhoppers were never found. The negative correlation at the Feniglia sites probably depended on the fact that the increasing order of sand compactness at the sites corresponded to an increasing order of tourist impact.

Furthermore, the sand compactness at $\mathrm{O} 1$, where sandhoppers were absent, was lower than at FB2 and FB1 where sandhoppers were present. Therefore, sand compactness does not seem to be a primary determinant of $T$. saltator population density. 
There did not appear to be any relationship between sandhopper abundance and sand grain size at the various sites. In fact, $T$. saltator lives on beaches with sand that ranges from medium- to coarse-grained (i.e. from around 0.5 to $2 \mathrm{~mm}$, Ugolini et al., 1995). All the locations considered in this study fell within this range.

The results for organic carbon suggested a negative correlation with sandhopper abundance at the Feniglia sandbar sites. However, as for sand compactness, the increasing order of organic carbon content at the sites corresponded to an increasing order of tourist impact. In addition, the FM site (MSRM Park) had a high sandhopper abundance but a higher organic carbon content than at FA where there were very few sandhoppers (but many swimmers).

The trace metal analysis confirmed T. saltator's good ability to bioaccumulate Hg, Cu, Cd and Zn (Rainbow and Moore, 1986; Moore and Rainbow, 1987; Rainbow, 1998; Rainbow et al., 1998a, b; Marsden and Rainbow, 2004; Ugolini et al., 2004, 2005). Although there were some differences in trace metal contamination among sites, there was no clear relationship with the abundance of sandhoppers. $\mathrm{Hg}$ accumulation seemed to be negatively correlated with sandhopper abundance at the various sites (Fig. 4). Nevertheless, the $\mathrm{Hg}$ concentration in the sand was lowest at $\mathrm{O} 1$ where there were no sandhoppers. Thus, the absence of sandhoppers at $\mathrm{O} 1$ and the low density at FA cannot be attributed to $\mathrm{Hg}$ contamination. Furthermore, the trace metal concentrations in both the sandhoppers and sand samples were much lower than those recorded previously at heavily polluted localities where sandhoppers or beachflies were present (Rainbow et al., 1998a, b; Fialkowski et al., 2000; Ugolini et al., 2004).

Since we did not evaluate the effects of beach cleaning separately from the effects of trampling, we cannot exclude a possible influence of beach cleaning on sandhopper density. Nevertheless, at the sampling sites not subjected to mechanical beach cleaning, sandhopper abundance still varied in relation to the different tourist impact. In fact, the sandhopper distributions along the Feniglia sandbar (where the

343 beach is regularly cleaned) and at Fiume Morto Vecchio and Batteria Vecchia (where

344 beach cleaning is not carried out) all presented the same pattern in relation to the 345 numbers of swimmers. Therefore, contrary to the hypothesis of Fanini et al. (2005), 346 trampling rather than beach cleaning has a negative effect on the survival of 347 sandhoppers. We can also add a qualitative datum: at site O1, the one with the highest 
348

349

350

351

352

353

354

355

356

357

358

359

360

361

362

363

364

365

366

367

368

369

370

371

372

373

374

375

376

377

378

379

tourist impact in the MSRM Park, we never captured any sandhoppers during the present research, whereas hundreds of sandhoppers were regularly collected around 25 years ago when the zone had no beach resorts and swimming was forbidden.

We studied populations living within $200 \mathrm{Km}$ of each other and thus subject to very similar general climatic and environmental conditions. Therefore, the natural fluctuations of population density are probably synchronous. In any case, since the proposed method is based on the comparison of densities recorded at the various sites in the same time period, it is independent of natural population fluctuations and does not require biodiversity estimates for the considered environment. Hence, the method is simple and low-cost. Other recently proposed methods using sandhoppers to assess human disturbance are based on quantification of the variability of spatial-temporal habitat use (ElGtari et al., 2002; Nardi et al., 2003; Fanini et al., 2005; Scapini et al., 2005) or on determination of the degree of genetic variability (Ketmaier et al., 2003). However, T. saltator's high behavioral plasticity and remarkable ability to learn new directions of the sea-land axis of the beach (see Ugolini and Macchi, 1988; Ugolini and Scapini, 1988; Ugolini et al., 1988) prevent a reliable and rapid determination of the reasons for variability in orientation behavior. The determination of genetic variability is interesting but not easily performed. Therefore, since these methods require specific expertise in various fields, sophisticated analytical techniques and complex statistical analyses, their practical application appears to be problematic.

The effect of human trampling and heavy tourist use of beaches on sandhopper populations raises the question of their conservation. T. saltator is a good osmoregulator (Morritt, 1988; Calosi et al., 2007) and metapopulations of this species are also found on the shores of retrodunal pools and on riverbanks near the mouth (Ugolini and Macchi, 1988; Ugolini and Scapini, 1988; Ugolini et al., 1988). These places are usually shunned by swimmers and if protected could be valid reserves for natural (spontaneous migrations) or artificial sandhopper repopulation of the adjacent beaches.

In conclusion, 1) our method is reliable and low-cost, 2) T. saltator is a good biomonitor of trace metal pollution $(\mathrm{Cu}, \mathrm{Hg}, \mathrm{Zn}, \mathrm{Cd})$, and 3$)$ this species is a valid bioindicator of the effects of human trampling and could be used for ecocompatible management of the tourist impact on the supralittoral zone. 


\section{Acknowledgments}

381

382

383

The research was funded by the Fondazione Monte dei Paschi (Siena), (grant

384 Interuniversitario di Biologia Marina (CIBM, Livorno) and the University of Florence

31017), Ente Parco Regionale di Migliarino, San Rossore, Massaciuccoli (Pisa), Centro

385 (local funds ex-60\%) assigned to A.Ugolini.

386

\section{References}

388 Anastácio, P.M., Gonçalves, S.C., Pardal, M.A., Marques, J.C., 2003. A model for

389 amphipod (Talitrus saltator) population dynamics. Estuarine Coastal and Shelf Science,

39058 (Supplement 1), 149-157.

391 Bergerard, J., 1989. Ecologie des laisses de marée. Année Biologique, 28, 39-54.

392 Branch, G., Branch, M., 1981. The living shores of Southern Africa. G. Struik Publication,

393 Cape Town, South Africa.

394 Brosnan, D.M., Crumrine, L.L., 1994. Effects of human trampling on marine rocky shore

395 communities. Journal of Experimental Marine Biology and Ecology, 177, 79-97.

396 Brown, A.C., McLachlan, A., 1994. Ecology of sandy shores. Elsevier: Amsterdam.

397 Calosi, P., Morritt, D., Chelazzi, G., Ugolini, A., 2007. Physiological capacity and

398 environmental tolerance in two sandhoppers species with contrasting geographical

399 ranges: Talitrus saltator and Talorchestia ugolinii. Marine Biology, 151, 1647-1655.

400 Chandrasekara, W.U., Frid, C.L.J., 1996. Effects of human trampling on tidalflat infauna.

401 Aquatic Conservation: Marine Freshwater Ecosystems, 6, 299-311.

402 Casu, D., Ceccherelli, G., Curini-Galletti, M., Castelli, A., 2006. Human exclusion from

403 rock shores in a Mediterranean marine protected area (MPA): An opportunity to

404 investigate the effects of trampling. Marine Environmental Research, 62, 15-32.

405 Dye A.H., 2006. Persistent effects of physical disturbance in mangrove sediments. Marine 406 Environmental Research, 62, 341-355.

407 ElGtari, M., Charfi - Chikhrouha, F., Marchetti, G.M., Scapini, F., 2002. Behavioural 408 adaptation of Talitrus saltator populations to beaches with different dynamics and 409 degree of human disturbance along Tunisian coasts. Polskie Archivium Hydrobiologii, $410 \quad 47,643-650$. 
411 Fanini, L., Cantarino, C.M., Scapini, F., 2005. Relationships between the dynamics of two

412 Talitrus saltator populations and the impacts of activities linked to tourism.

413 Oceanologia, 47, 93-112.

414 Fialkowski, W., Rainbow, P.S., Fialkowska, E., Smith, B.D., 2000. Biomonitoring of trace

415 metals along the Baltic Coast of Poland using the sandhopper Talitrus saltator

416 (Montagu) (Crustacea: Amphipoda). Ophelia, 52, 183-192.

417 Griffiths, C.L., Stenton - Dozeyand, J.M.E., Koop, K., 1983. Kelp wrack and the flow of

418 energy through a sandy beach ecosystem. In: McLachlan, A., Erasmus, T. (Eds.). Sandy

419 beaches as ecosystems. W. Junk Publishers, The Hague, Netherlands, 547-556 pp.

420 Jaramillo, E., Contreras, H., Quijon, P., 1996. Macroinfauna and human disturbance in a

421 sandy beach of south-central Chile. Revista Chilena de Historia Naturale, 69, 655-663.

422 Johnson, G.E.L., Attrill, M.J., Sheehan, E.V., Somerfield, P.J., 2007. Recovery of

423 meiofauna communities following mudflat disturbance by trampling associated with

424 crab-tiling. Marine Environmental Research, 64, 409-416.

425 Ketmaier, V., Scapini, F., De Matthaeis, E., 2003. Exploratory analysis of talitrid

426 population genetics as an indicator of the quality of sandy beaches. Esturine Coastal and

427 Shelf Science, 58 (supplement 1), 159-167.

428 Liddle, M.J., 1975. A selective review of the ecological effects of human trampling on

429 natural ecosystems. Biological Conservation, 7, 17-36.

430 Marsden, I.D., Rainbow, P.S., 2004. Does the accumulation of trace metals in Crustaceans

431 affect their ecology - the Amphipods example? Journal of Experimental Marine

432 Biology and Ecology, 300, 373-408.

433 Marques J.C., Gonçalves, S.C.,. Pardal, M.A., Chelazzi, L., Colombini, I., Fallaci, M.,

434 Bouslama, M.F., El Gtari, M., Charfi - Cheikhrouha, F., Scapini, F., 2003.

435 Compararision of Talitrus saltator (Amphipoda, Talitridae) biology, dinamics, and

436 secondary production in Atlantic (Portugal) and Mediterranean (Italy and Tunisia)

437 populations. Estuarine Coastal and Shelf Science, 58 (supplement 1), 127-148.

438 Milazzo, M., Chemello, R., Badalamenti, F., Camarda, R., Riggio, S., 2002. The impact of

439 human recreational activities in marine protected areas: What lessons should be learnt in

440 the Mediterranean Sea. Marine Ecology, 23 (supplement 1), 280-290.

441 Moffet, M.D., McLachlan, A., Winter, P.E.D., De Ruyck, A.M.C., 1998. Impact of

442 trampling on sandy beach macrofauna. Journal of Coastal Conservation, 4, 87-90. 
443 Moore, P.G., Rainbow, P.S., 1987. Copper and zinc in an ecological series of talitroidean 444 Amphipoda (Crustacea). Oecologia, 73, 120-126.

445 Morritt, D., 1988. Osmoregulation in littoral terrestrial talitroidean amphipods (Crustacea) 446 from Britain. Journal of Experimental Marine Biology and Ecology, 123, 77-94.

447 Nardi, M., Morgan, E., Scapini, F., 2003. Seasonal variation in the free-running period in 448 two Talitrus saltator populations from Italian beaches differing in morphodynamics and 449 human disturbance. Estuarine Coastal and Shelf Science, 58 (supplement 1), 199-206.

450 Palluault, M., 1954. Notes ecologiques sur le Talitrus saltator. Archives de Zoologie 451 Expérimentale et Générale, 91, 105-129.

452 Povey, A., Keough, M.J., 1991. Effects of trampling on plant and animal populations on 453 rocky shores. Oikos, 61, 355-368.

454 Rainbow, P.S., 1998. Phylogeny of trace metal accumulation in crustaceans. In: Langston, 455 W.J., Bebianno, M.J. (Eds.). Metal metabolism in aquatic environment. Chapman and 456 Hall, London, 285-319 pp.

457 Rainbow, P.S., Moore, P.G., 1986. Comparative metals analyses in amphipod crustaceans. 458 Hydrobiologia, 141, 273-289.

459 Rainbow, P.S., Fialkowski, W., Smith, B.D., 1998a. The sandhopper Talitrus saltator as a 460 trace metal biomonitor in the Gulf of Gdansk, Poland. Marine Pollution Bulletin, 36, $461 \quad 193-200$.

462 Rainbow, P.S., Moore, P.G., Watson, D., 1998b. Talitrid amphipods (Crustacea) as 463 biomonitors for copper and zinc. Estuarine Coastal and Shelf Science, 28, 567-582.

464 Scapini, F., Chelazzi, L., Colombini, I., Fallaci, M., Fanini, L., 2005. Orientation of 465 sandhoppers at different points along a dynamic shoreline in southern Tuscany. Marine 466 Biology, 147, 919-926.

467 Schlacher, T.A., Dugan, J., Schoeman, D.S., Lastra, M., Jones, A., Scapini, F., 468 McLachlan, A., Defeo, O., 2007. Sandy beaches at the brink. Diversity and 469 Distributions, 13, 556-560.

470 Shepard, F.P., 1954. Nomenclature based on sand - silt - clay ratios. Journal of 471 Sedimentary Petrology, 24, 151-158.

472 Siegel, S., Castellan Jr., J.N., 1989. Non parametric statistics for the behavioral sciences, 473 2nd edn. McGraw Hill, New York. 
474 Ugolini, A., Macchi, T., 1988. Learned component in the solar orientation of Talitrus

475 saltator Montagu (Amphipoda : Talitridae). Journal of Experimental Marine Biology

476 and Ecology, 121, 79-87.

477 Ugolini, A., Scapini, F., 1988. Orientation of the sandhopper Talitrus saltator

478 (Amphipoda, Talitridae) living on dynamic sandy shores. Journal of Comparative

479 Physiology, 162, 453-462.

480 Ugolini, A., Scapini, F., Beugnon, G., Pardi, L., 1988.Learning in zonal orientation of

481 sandhoppers. In: Chelazzi, G., Vannini, M. (Eds.). Behavioural adaptation to intertidal

482 life. NATO ASI Series A, 151, Plenum Press, London-New York, 115-118 pp.

483 Ugolini, A., Felicioni, S., Ruffo, S., Cipriani, L., 1995. Distribution of Talorchestia

484 ugolinii and other sandhoppers in Corsica. Bollettino di Zoologia, 62, 291-296.

485 Ugolini, A., Borghini, F., Calosi, P., Bazzicalupo, M., Chelazzi, G., Focardi, S., 2004.

486 Mediterranean Talitrus saltator (Crustacea, Amphipoda) as a biomonitor of heavy

487 metals contamination. Marine Pollution Bulletin, 48, 526-532.

488 Ugolini, A., Borghini, F., Focardi, S., Chelazzi, G., 2005. Heavy metals accumulation in

489 two syntopic sandhoppers species: Talitrus saltator Montagu and Talorchestia ugolinii

490 Bellan Santini and Ruffo. Marine Pollution Bulletin, 50, 1328-1334.

491 Veloso, V.G., Silva, E.S., Caetano, C.H.S., Cardoso, R.S., 2006. Comparison between the

492 macrofauna of urbanized and protected beaches in Rio de Janeiro State, Brazil.

493 Biological Coservation, 127, 510-515.

494 Weslawski, J.M., Kupidura, K., Zabicki, M., 2000a. Sandhoppers, Talitrus saltator

495 (Montagu), at the Polish Baltic coast: seasonal and spatial distribution patterns.

496 Crustaceana, 73, 961-969.

497 Weslawski, J.M., Stanek, A., Siewert, A., Beer, N., 2000b. The sandhopper Talitrus

498 saltator (Montagu) on the Polish Baltic coast. Is it a victim of increased tourism?

499 Oceanological Studies, 29, 77-87.

500 Weslawski, J.M., Urban - Malinga, B., Kotwicki, L., Opalinski, K., Szymelfenig, M.,

501 Dutkowski, M., 2000c. Sandy coastlines: are there conflicts between recreation and

502 natural values? Oceanological Studies, 29, 5-18.

503 Wildish, D.J., 1988. Ecology and natural history of aquatic Talitroidea. Canadian Journal

504 of Zoology, 66, 2340-2359.

505 Zar, J.H., 1984. Biostatistical Analysis, $2^{\text {nd }}$ ed. Prentice-Hall, New Jersey. 


\section{ACCEPTED MANUSCRIPT}

506

507

508

509

510

51

512

513

514

515

516

517

518

519

520

521

522

523

524

525

526

527

528

529

530

531

532

533

534

535

536

537

\section{Table captions}

Table 1. Captured sandhoppers and number of swimmers (mean $\pm \mathrm{SD} ; \mathrm{n}=3$ ) for each month of sampling

Table 2. Results of the granulometric analysis for each sampling site. For further explanations, see Figs. 1, 3 and text.

\section{Figure captions}

Fig. 1. Frequency (\% of total numbers) of captured sandhoppers (black bars) and swimmers (white bars) for each month of sampling. The order of the sampling sites is based on the number of swimmers observed at each locality: FM = Fiume Morto; BV = Batteria Vecchia; $\mathrm{SF}=$ Serchio Fiume; $\mathrm{SM}=$ Serchio Mare; $\mathrm{O} 1$ = Oasi 1 . The total numbers of sandhoppers and swimmers at all five sites are also given.

Fig. 2. Monthly variation of sandhopper numbers (\% of total sampled) at Fiume Morto (FM). Total number of sandhoppers collected $=5199$.

Fig. 3. Frequency (\% of total numbers) of captured sandhoppers (black bars) and swimmers (white bars) along the Feniglia sandbar in July and September. The order of the sampling sites is based on the number of swimmers observed at each locality: FA = Feniglia bathhouse, FB1 = $1 \mathrm{~km}$ from bathhouse, FB2 $=2 \mathrm{~km}$ from bathhouse. The total numbers of sandhoppers and swimmers at all three sites are also given.

\section{Fig. 4. Trace metal concentrations ( $\mu \mathrm{g} \mathrm{g}^{-1} \mathrm{dry} \mathrm{wt}$ ) in the sand (white bars) and in the} sandhoppers (black bars). For each element, the sampling sites are ordered according to decreasing frequency of sandhoppers recorded in July 2006. For further explanations, see Figs. 1, 3 and text. 
539 Fig. 5. A-B: mean sand grain diameter (white bars) and frequency of captured

540 sandhoppers (black bars; \% of total numbers). The order of the sampling sites is based

541 on mean diameter. C-D: sand compactness (white bars) expressed in arbitrary units (a.

542 u.) and frequency of captured sandhoppers (black bars). The order of the sampling sites

543 is based on sand compactness. E-F: percentage of organic carbon in the sand (white

544 bars) and frequency of captured sandhoppers (black bars). The order of the sampling

545 sites is based on percentage of organic carbon. For further explanations, see Figs. 1 and 5463.

547

548 Fig. 6. Frequency of surviving sandhoppers subjected to the trampling test (black bars)

549 and controls (white bars). Before $=$ before the test, After $=$ after the test, $24 \mathrm{~h}=24$ hours 550 after the beginning of the test. See text for further details. 

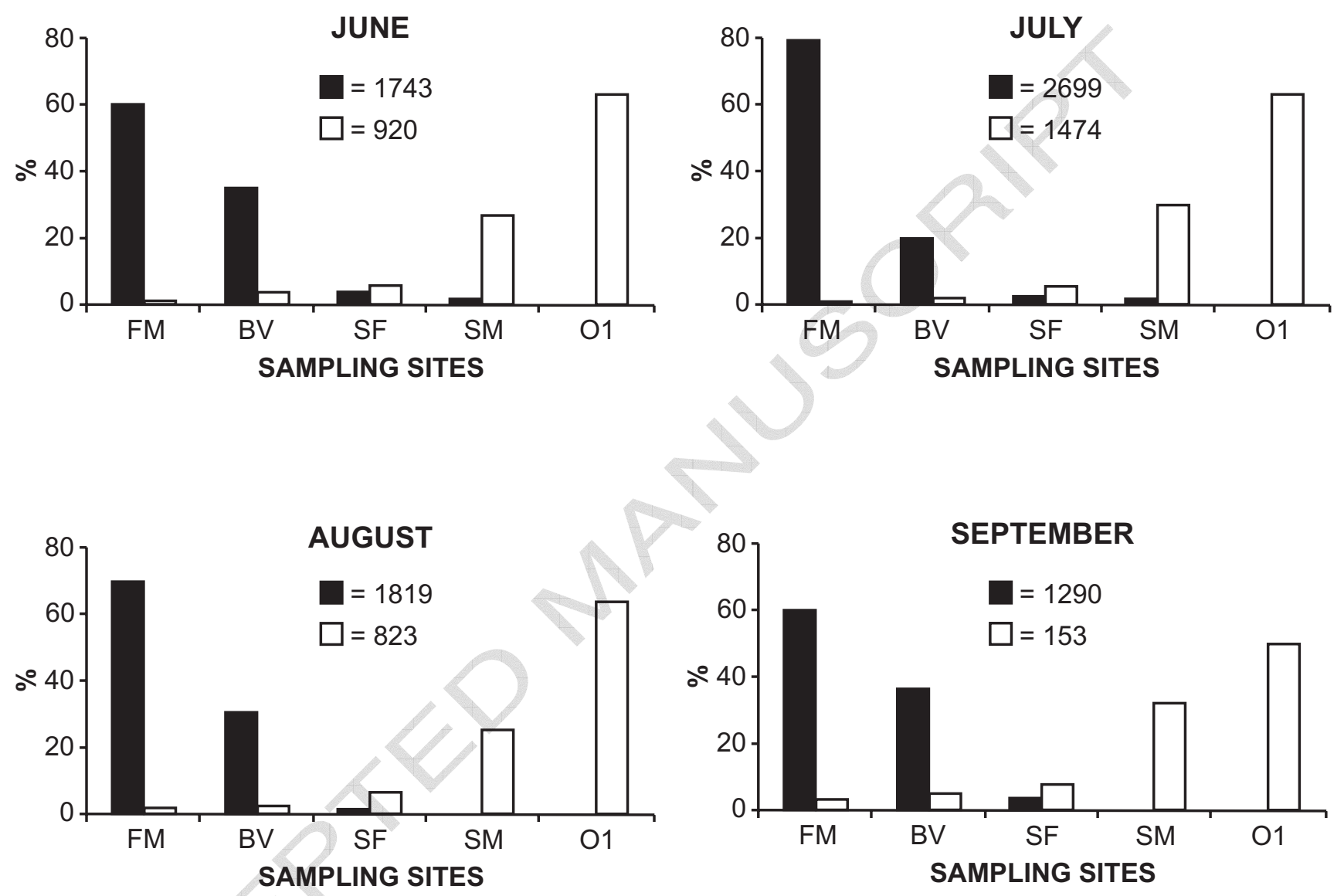

Figure 1 


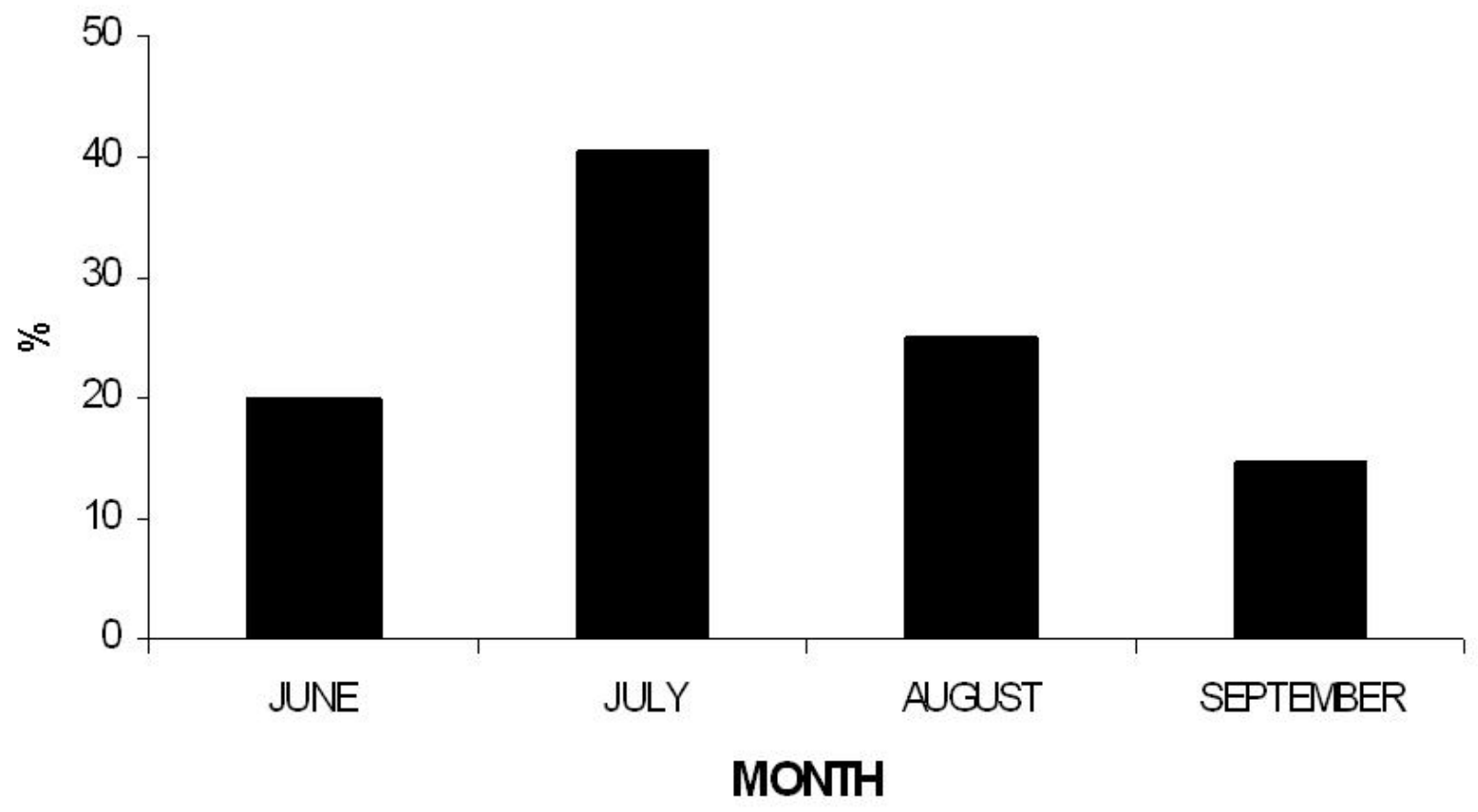

Figure 

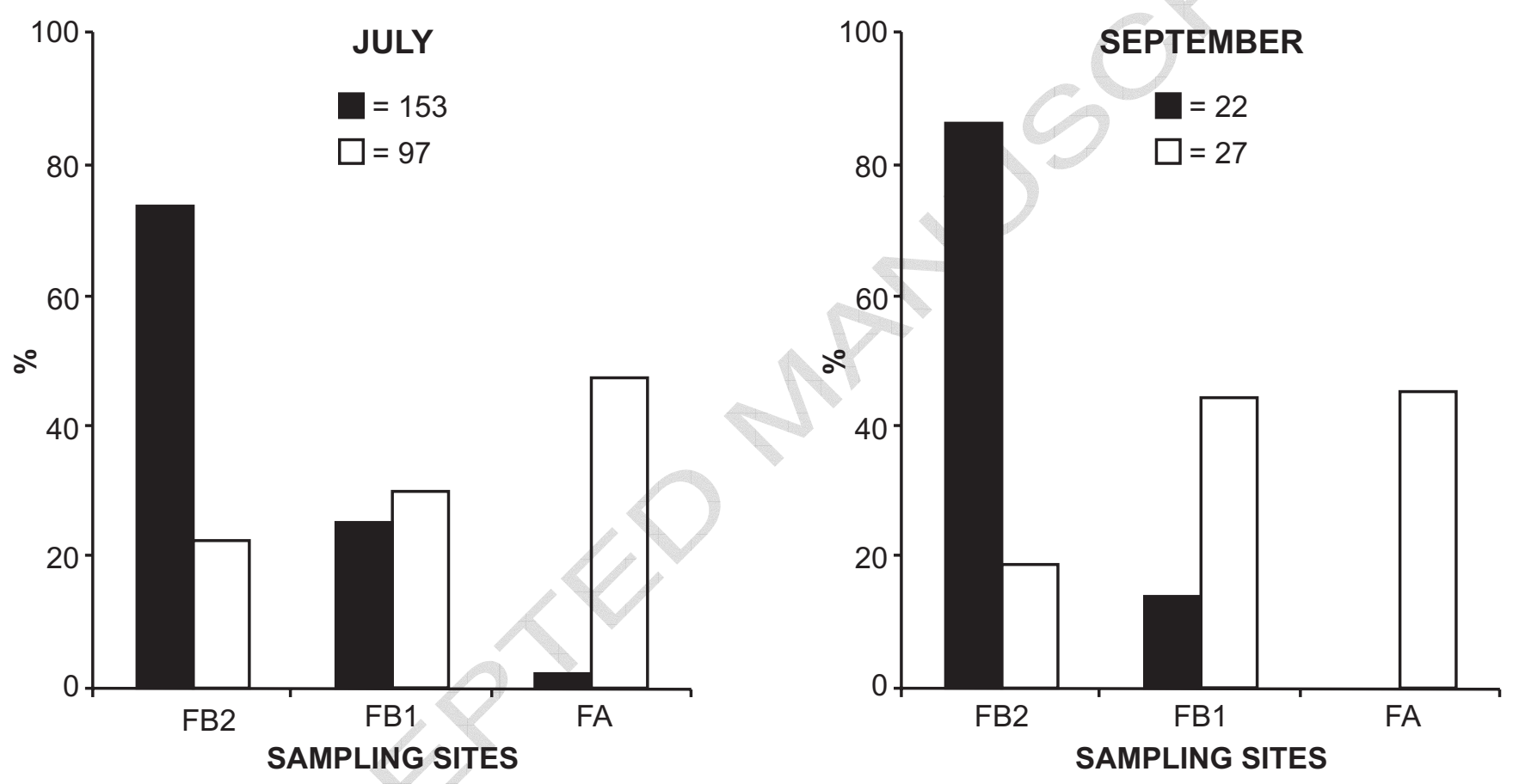

Figure 3 
Hg

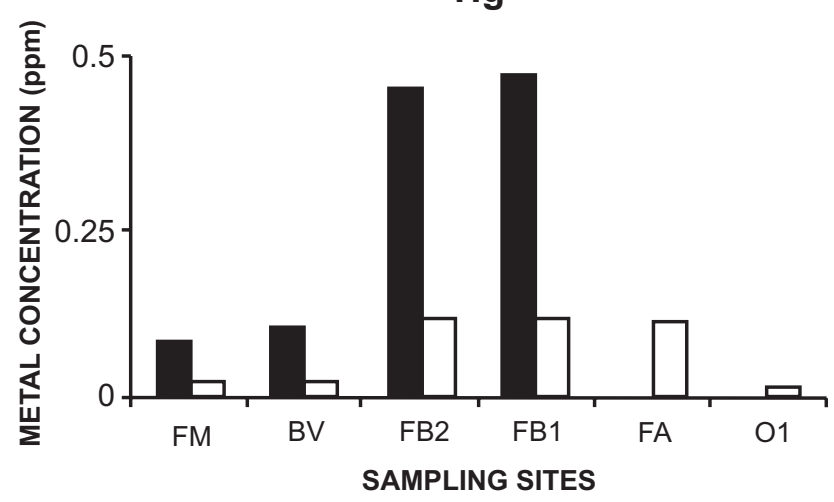

Cd
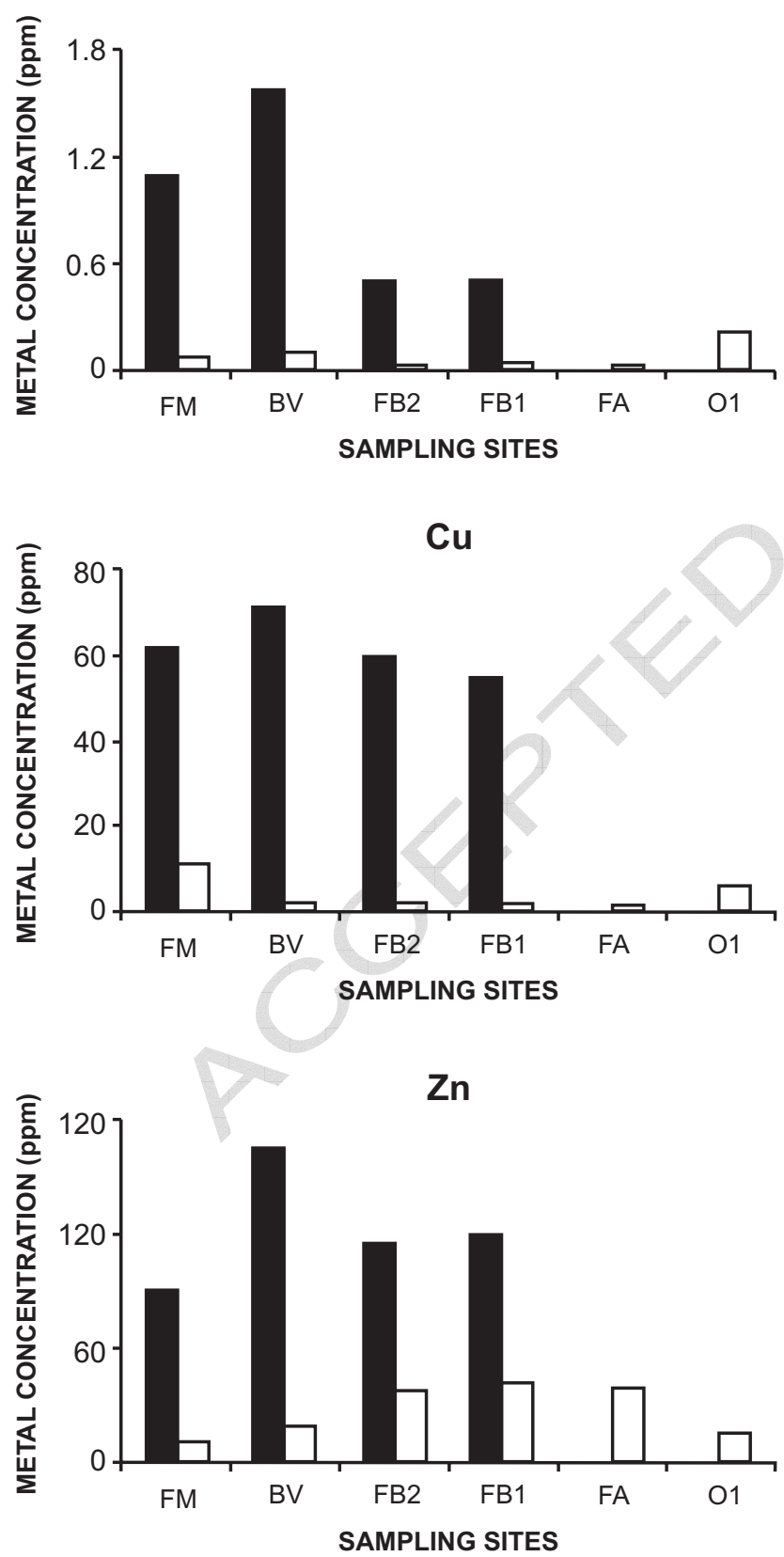

$\mathrm{Pb}$

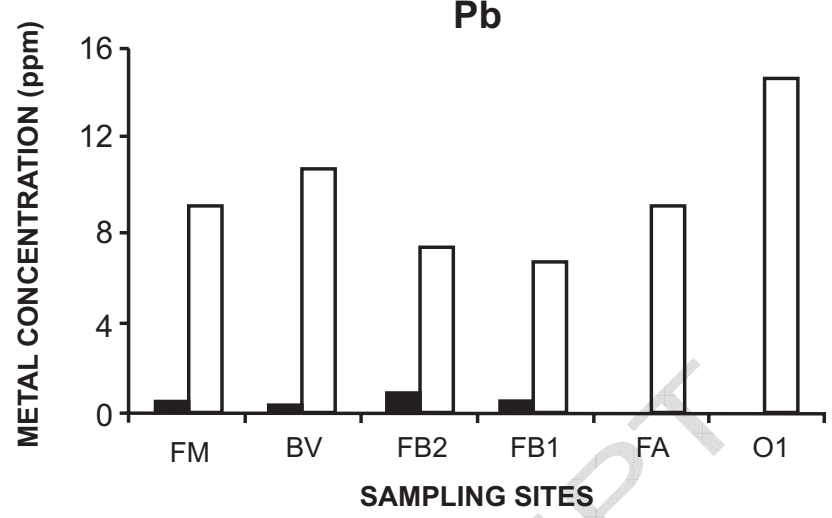

Al

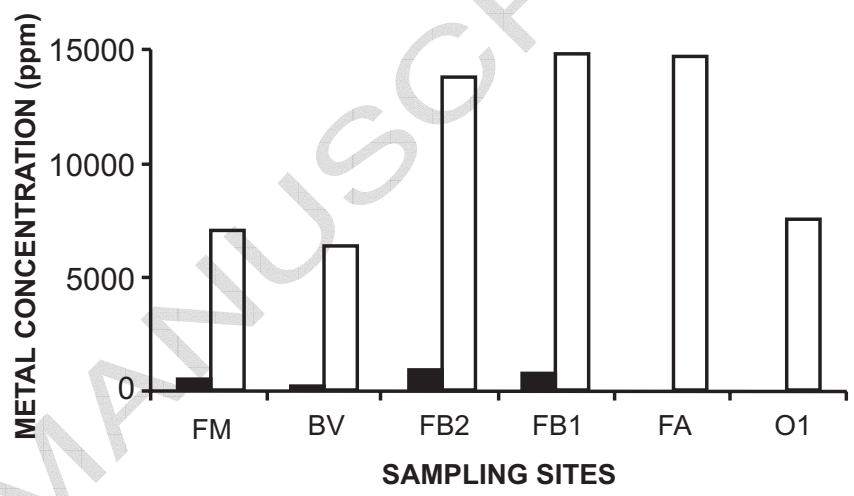

$\mathrm{Fe}$
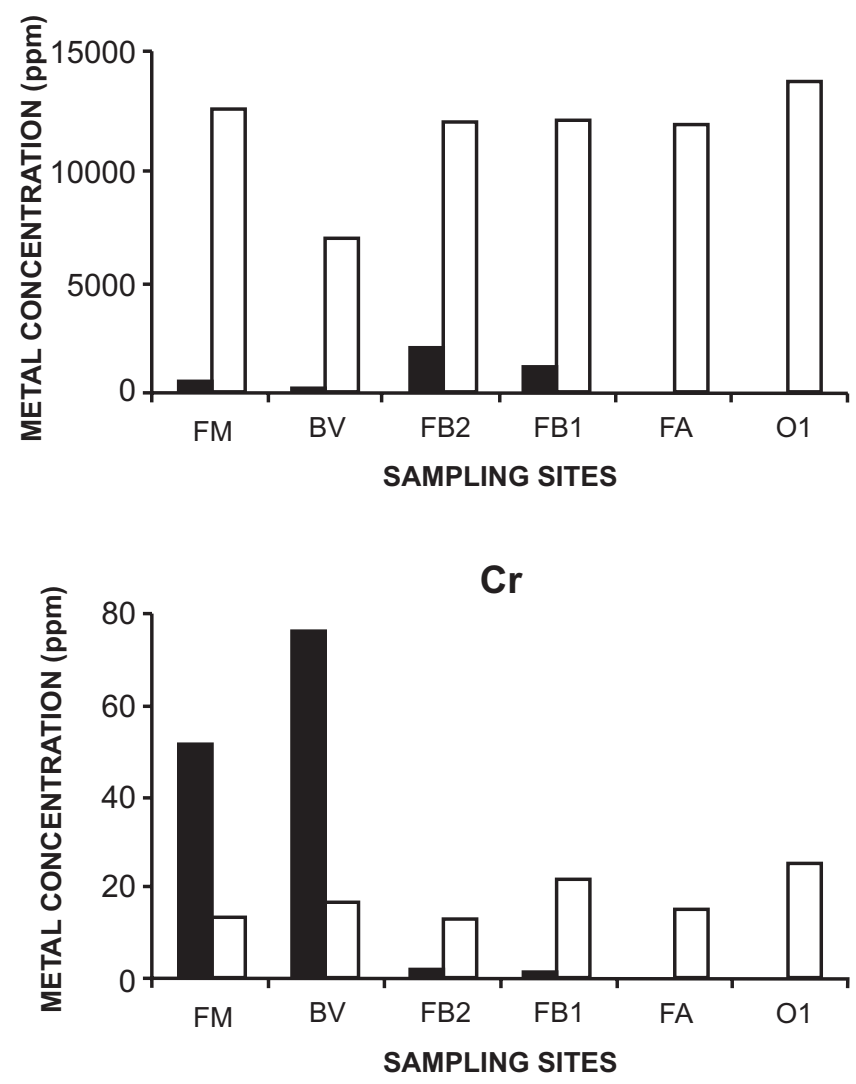

Figure 4 
GRANULOMETRY
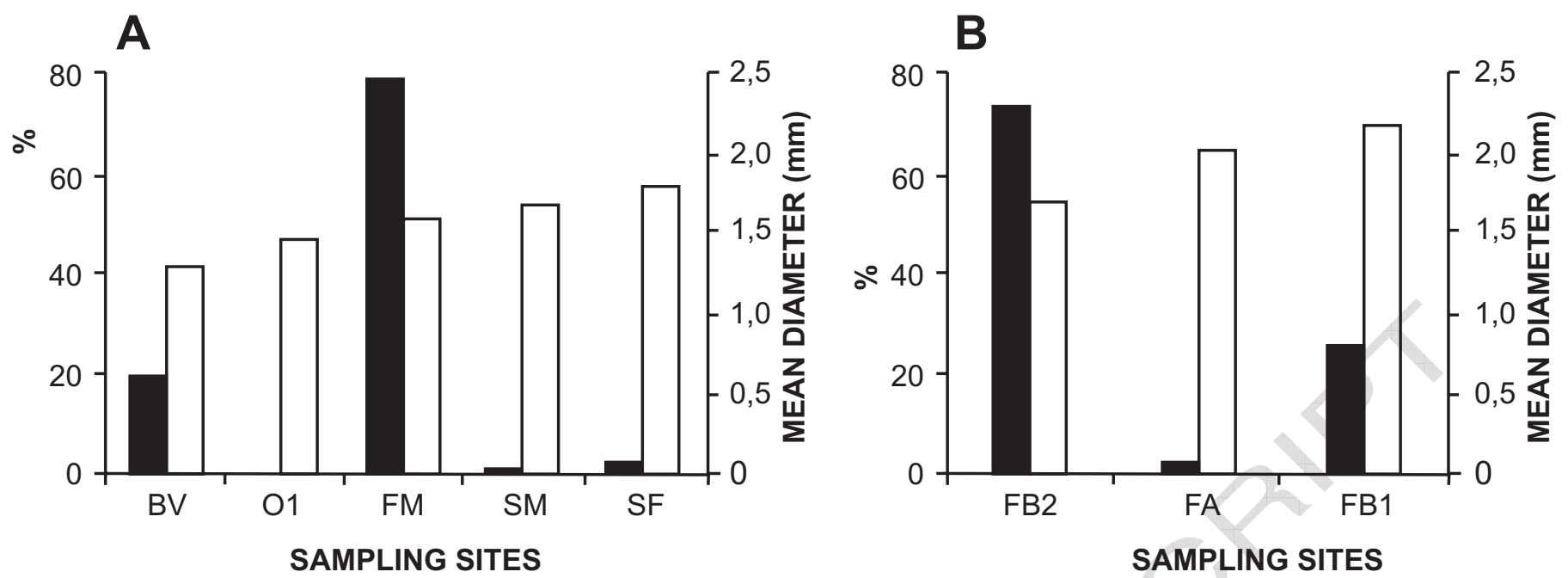

SAND COMPACTNESS
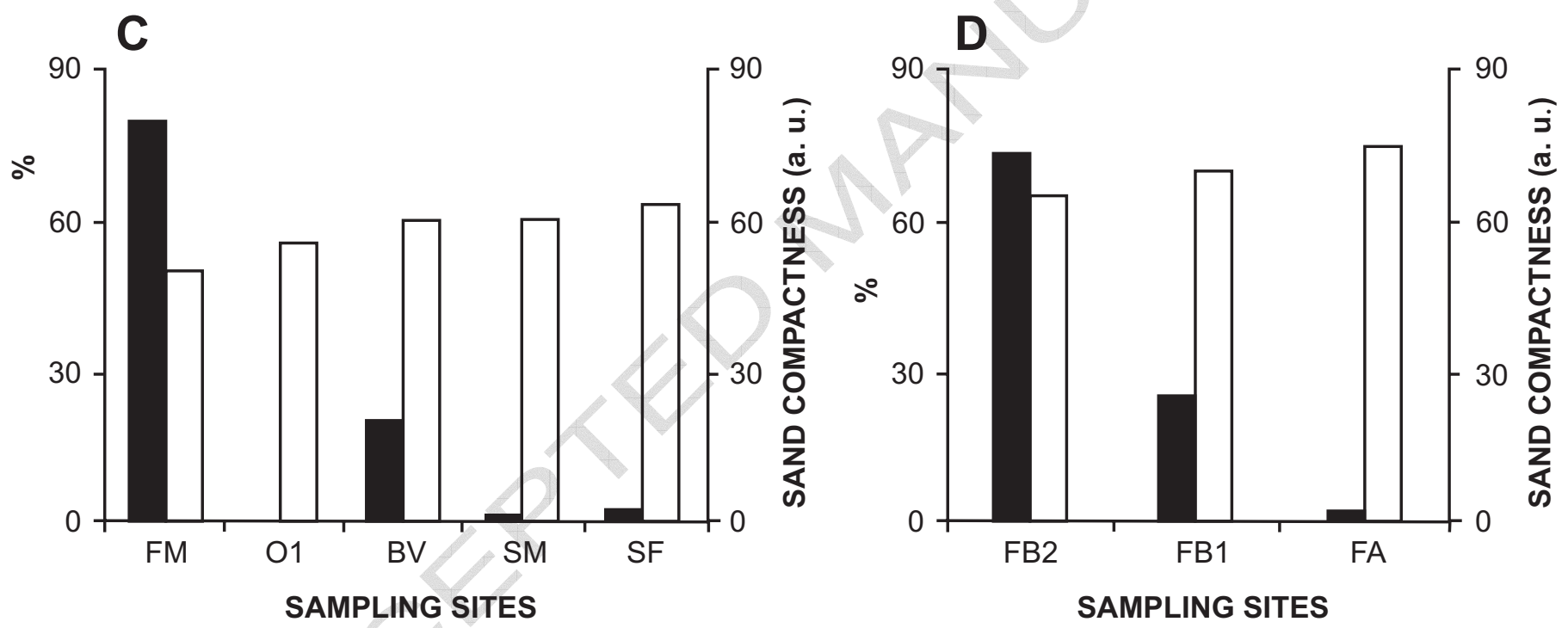

\section{ORGANIC CARBON}
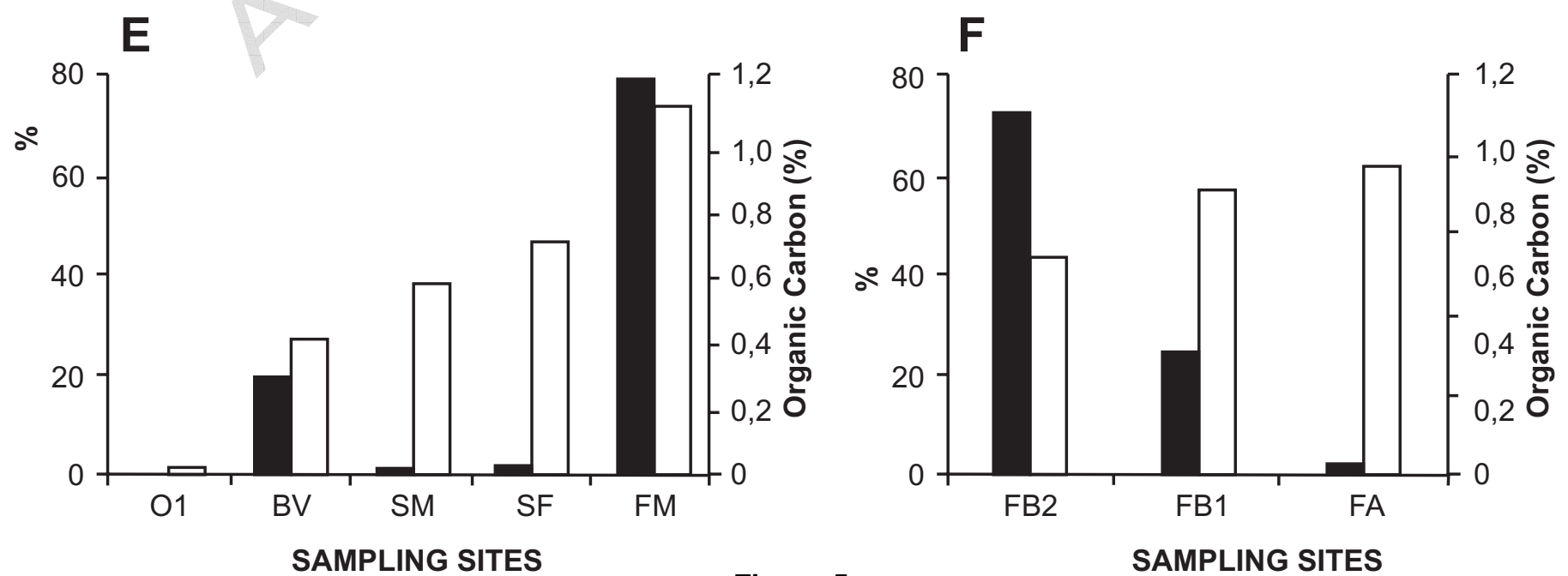

Figure 5 


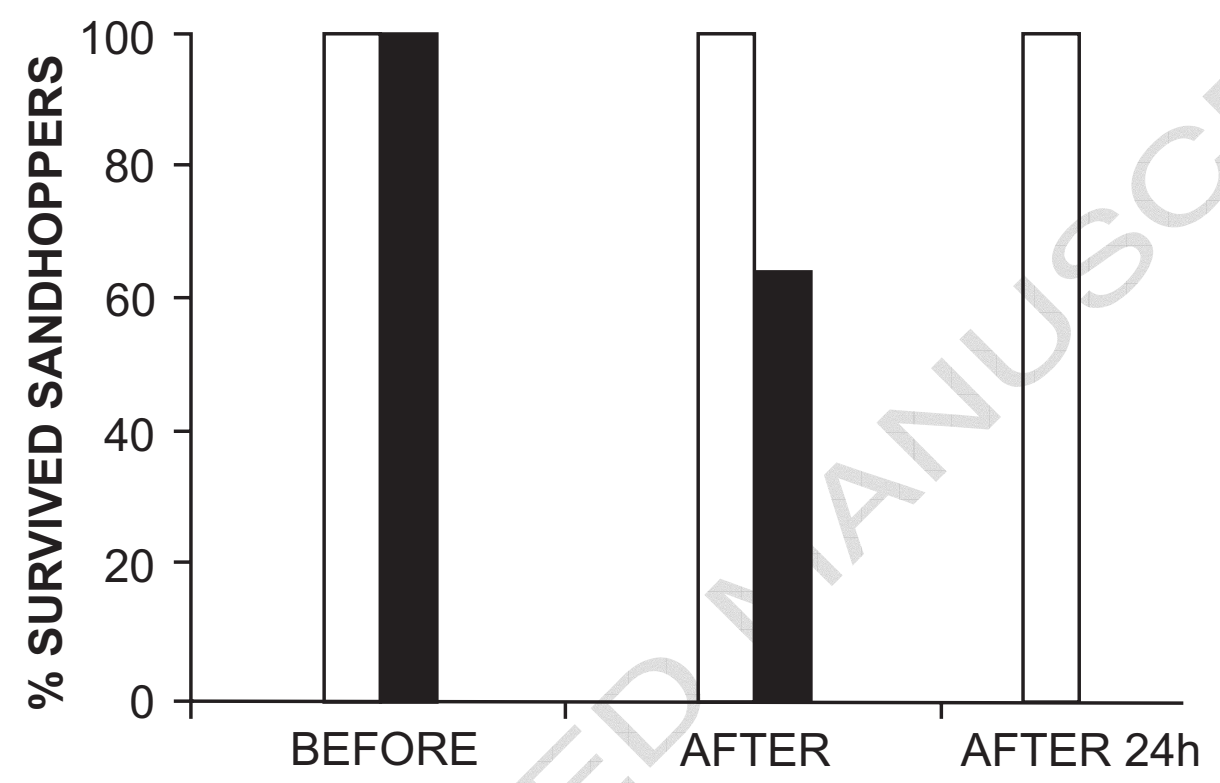

Figure 6 


\section{ACCEPTED MANUSCRIPT}

\begin{tabular}{lccccc}
\hline \multicolumn{2}{l}{ Sampling sites } & June & July & August & September \\
\hline FM & sandhoppers & $348.3 \pm 59$ & $709 \pm 332$ & $438 \pm 466$ & $256 \pm 325$ \\
& swimmers & $1.3 \pm 1.5$ & $4 \pm 2$ & $3.6 \pm 4.4$ & $1.66 \pm 1.5$ \\
BV & sandhoppers & $204 \pm 85$ & $174 \pm 40$ & $184.6 \pm 104$ & $158 \pm 192$ \\
& swimmers & $10 \pm 13$ & $6 \pm 2.6$ & $6.6 \pm 9$ & $1.3 \pm 1.5$ \\
SF & sandhoppers & $21 \pm 31$ & $15 \pm 15$ & $2.3 \pm 4$ & $16.3 \pm 18$ \\
& swimmers & $18 \pm 19$ & $25.6 \pm 15$ & $18.6 \pm 12$ & $4.3 \pm 5$ \\
SM & sandhoppers & $8 \pm 12$ & $1.33 \pm 1.5$ & 0 & 0 \\
& swimmers & $82 \pm 70$ & $146 \pm 137$ & $70 \pm 21.2$ & $16.6 \pm 13.5$ \\
O1 & sandhoppers & 0 & 0 & 0 & 0 \\
& swimmers & $196 \pm 190$ & $310 \pm 134$ & $175 \pm 76$ & $28.6 \pm 17.8$ \\
\hline
\end{tabular}

Table 


\section{ACCEPTED MANUSCRIPT}

\begin{tabular}{ccccc}
$\begin{array}{c}\text { Sampling } \\
\text { sites }\end{array}$ & $\begin{array}{c}\text { Mean sand } \\
\text { grain diameter } \\
(\mathrm{mm})\end{array}$ & $\begin{array}{c}\text { Standard } \\
\text { deviation }\end{array}$ & Skewness & Kurtosis \\
\hline FM & 1.605 & 0.471 & -0.012 & 0.503 \\
BV & 1.324 & 0.507 & 0.247 & 0.494 \\
SF & 1.751 & 0.506 & 0.180 & 0.598 \\
SM & 1.669 & 0.469 & 0.051 & 0.582 \\
O1 & 1.484 & 0.486 & 0.170 & 0.543 \\
FB2 & 1.738 & 0.436 & 0.234 & 0.631 \\
FB1 & 2.166 & 0.435 & -0.043 & 0.511 \\
FA & 2.032 & 0.489 & 0.065 & 0.552 \\
\hline
\end{tabular}

Table 